\title{
Entrepreneurial Orientation as a Panacea for the Ebbing Productivity in Nigerian Small and Medium Enterprises: A Theoretical Perspective
}

\author{
Prof. Amos S. Ogunsiji \\ Department of Management and Accounting \\ Ladoke Akintola University of Technology, Ogbomoso, Oyo State, Nigeria \\ E-mail: amosogunsiji@yahoo.com
}

Ladanu, William Kayode (Corresponding author)

Department of Business Administration, Bowen University, Iwo, Osun State, Nigeria

P.M.B. 284, IWO, OSUN STATE, NIGERIA

Tel: 234-803-502-8971 E-mail: kayladanu@yahoo.com

\begin{abstract}
Small and Medium enterprises are widely distributed in the Nigerian economy and they are major contributors to the socio-economic development of the nation. However, some salient features of these enterprises and the dynamic nature of a highly global economy makes the effective and efficient contributions of these enterprises unattainable. The central argument of this paper is that entrepreneurial orientation is the panacea to this ebbing productivity.
\end{abstract}

Accordingly, the paper provides deeper understanding of the cross-functional activities in the behaviour-embedded nature of innovation, proactivity, autonomy, risk-taking propensity and competitive aggressiveness.

Keywords: Entrepreneurial Orientation, Productivity, Small and Medium Enterprises, Synergistic Management

\section{Introduction}

In many developing countries, the Small and Medium Enterprises (SMEs) constitute the bulk of the industrial base and contribute significantly to their exports as well as to their GDP or GNP (Kharbanda, 2001). In Nigeria, the Small and Medium Enterprises constitute 99 percent of the enterprises in the country. (OECD, 1998). Further, they account for 70 percent of national industrial employment. (Adebusuyi, 1997). These enterprises have immense contributions to economic growth, job creation and industrial development (OECD, 2004; Hallberg, 2000; Carree and Thurik, 2005; NIPC, 2004). According to Beyene (2002), "the potentials of the small and medium enterprises are manifested in their labour-intensive nature, income-generating possibilities, capital saving capacity, potential use of local resources and reliance on few imports, flexibility, innovativeness and strong linkages with the other sectors of the economy." This basically explains the reason why SMEs are the darling of policy makers and governments all over the world (Beyene, 2002; Ladanu, 2009).

In Nigeria, the governments at various levels have formed different policy incentives aimed at boosting the performance of small businesses in order to reduce the level of poverty and enhance economic development (Akande and Ojokuku, 2008). Accordingly, the Nigerian governments acting alone and sometimes in concert with international agencies had formulated and implemented policies and programs that center on finance, training and the provision of infrastructure for the SMEs. Inyang and Enuoh (2009) opine most researchers concentrated on finance as the major impediment to successful entrepreneurship or small scale business.

The above are the manifestations of the importance and shortcomings of the SMEs. The firms operate in turbulent environments which call for great tenacity on their resources in order to take advantage of emerging opportunities (Tecce, Pisano, and Schuen, 1997). In this context, the firm's strategy, which, according to Wiklund and Shepherd (2003), is "conceptualised in terms of its entrepreneurial orientation", becomes important. Miller (1983) considers a firm's entrepreneurial orientation to consist of its risk-taking propensity, proactiveness and innovation. Lumpkin and Dess (1996) added the dimensions of competitive aggressiveness and autonomy. A number of researches suggest a positive association of entrepreneurial orientation with financial performance. (Miller, 1983; Zahra, 1993; Covin and Slevin, 1989). Also, there abounds, in extant literature, theoretical evidences that relate the effects of entrepreneurship on the economy. (Baumol, 1993; Lumpkin and Dess, 1996). Entrepreneurship is missing from most empirical models explaining economic growth (Wong, Ho, and Autio, 
2005). Consequently, entrepreneurial orientation has not been put in its proper place in respect of firm productivity.

The objective of this paper is to critically examine the state of the small and medium enterprises in Nigeria and highlight the import of entrepreneurial orientation as the solution to the productivity problem of these SMEs.

This paper makes the following contributions to the extant literature in the following ways. First, it furthers our understanding of how a firm's strategic orientation (in this case the entrepreneurial orientation) influences the productivity and hence the performance of the firm. A better understanding of some underlying entrepreneurial orientation dimensions that determine or enhance productivity is significant. Second, by considering the potential influences of entrepreneurial orientation as a set of behaviours exhibited by the entrepreneurs on firm productivity, a better understanding of how entrepreneurial orientation drives and is being implemented across the many functional activities within the firm is attained.

\section{Characteristics and State of SMEs in the Nigerian Economy}

The SMEs are the arrowheads of industrialisation in many developing as well as developed economies. A major step to understanding SMEs is to have a definition. However, there is no widely accepted definition of SMEs in Africa (Beyene, 2002). In Nigeria, the definition has changed from time to time and differs from one agency to another, using variables that range from the number of employees, capital employed and turnover. Table 1.

This paper considers, as satisfactory, the definition of SMEs by the Small and Medium Industries Equity Investment Scheme (SMIEIS) which defines SMEs as enterprises with a total capital employed not less than $=\mathrm{N}=1.5$ million, but not exceeding $=\mathrm{N}=200$ million, including working capital, but excluding cost of land and/or with a staff strength of not less than 10 and not more than 300. The SMIEIS is a scheme set up by the Banker's Committee, a body that consists of representatives of banks in Nigeria. The scheme requires all banks to set aside 10 percent of their Profit before Tax (PBT) for participation as equity investments in Small and Medium Enterprises in the country.

The Small and Medium Enterprises are widely distributed in many economies. The Small and Medium Enterprises represent the fountainhead of vitality for the industrialisation process of the economy (Ogun and Anyanwu, 1999). In Nigeria, Aluko, Oguntoye, and Afonja (1975) characterised SMEs as follows:

1) "The same manager or proprietor finds it difficult to raise short or long term capital from the organized capital market, instead relies on personal savings or loans from friends, relatives or money lenders.

2) The same manager/proprietor handles/supervises the production, financing, marketing and personnel functions of the enterprise.

3) The manager/proprietor's vision is confined to the local community in which he carries on his line of business. There is little or no knowledge of the wider or distant markets.

4) The rate of business mortality is high probably because of strong mutual distrust and dominance of the sole proprietor which militates against the formation of partnerships or limited liability companies.

5) The enterprise is generally poorly equipped as the small scale industrialist feels reluctant to accept outside help owing to prejudice or fear that information about the enterprise might reach the tax authorities or a nearby competitor.

6) Little or no account of business costs or revenue is kept and the banking system is hardly utilized. The result is that banking facilities for business financing and expansion are extended to only very few of the industrialists.

7) The level of education of the proprietor is usually very low with a consequent low level of business management technique, skill or market information."

The above features of the small scale enterprises in Nigeria, succinctly point to the necessity for more entrepreneurial approach to the management of these enterprises.

Notwithstanding these characteristics of the Small and Medium Enterprises in Nigeria, these enterprises are highly important to the extent that they are expected among others,

to:

a. Provide the avenue for the birth and growth of indigenous entrepreneurs (Ogun and Anyanwu, 1999).

b. Serve as a conduit for the mobilisation of savings into the real sector of the economy.

c. Being labour-intensive, provide jobs for the unemployed, 
d. Accentuate the even and balance development of the nation.

\section{Entrepreneurial Orientation and the Productivity of SMEs in Nigeria.}

Many SMEs, particularly in the developing countries face monumental challenges. Despite the lofty objectives of policies and practitioners, the results from SME programs and policies are often disappointing and the potential contributions that vigorous small-scale industry could make to development programs are not realised (Lebell, Schultz, and Weston, 1974). In Nigeria Ogunsiji (2002a) identified these challenges to include

a. Poor utility services

b. Poor managerial and technical skills development

c. "Low productivity and low-quality output, particularly of the manufacturing sector" (Adegbite et al., 2007).

d. Poor access to and in some cases inadequate finance, which is considered the most worrisome and tops the list for most SMEs (Beyene, 2002; Oludimu and Ogunsiji, 1994; Ogunsiji, 2002a; 2004; 2005; Akande and Ojokuku, 2008; Olutunla and Obamuyi, 2008).

In Nigeria, as well as in other developing economies, a number of measures that include technical/managerial training, provision of credit facilities (establishment of various financial institutions), establishment of industrial estates and of recent, the establishment of business incubators (Adegbite, 2001), physical facilities in many of other developmental plans are being put in place to ameliorate these challenges, (Ogunsiji, 2002a; 2004) in separate studies. Beyene (2002), opines that "a government that is genuinely committed to the development of SMEs needs to ensure a support strategy that judiciously combines entrepreneurial, technological and managerial competence with real market opportunities and access to resources." The entrepreneur is a significant phenomenon at ensuring improved productivity and hence increased performance of the Small and Medium Enterprises in Nigeria. Particularly considering the fact that they operate in highly turbulent environment with various handicaps especially finance. Productivity, according to Roberts and Tybout (1997) refers to "the measure of the relationship between the quantity of output and the quantity of resources needed in producing a particular good or service." It is most times considered as output per unit of input. Therefore, achieving increased productivity or the same volume of output using less resources is paramount to managers. This is achieveable through what Ogunsiji (2002b) referred to as innovative entrepreneurship which breeds distinctive competences difficulty-to-imitate.

According to Ogunsiji and Anene (1994) "making work and resources productive and the worker an achiever is the greatest challenge to the management task." (Table 2). The industrial capacity utilisation of the Nigerian enterprises, particularly in the manufacturing sector, is also very low. (Table 3 ).

This below average syndrome may be improved applying adaptive strategic management process through competence building and competence leveraging and future-focused innovation on a continuous basis. (Ogunsiji, 2004; 2005)

The entrepreneur is undoubtedly vital aspect of production. The one who, according to Gartner (1985), creates a new organisation or founds a new business venture. The entrepreneur, in many cases, as the gatekeeper, has the sole responsibility to properly source and utilise the organisation's resources and capabilities through matched strategies to a productive end. According to $\mathrm{Yu}$ (2001), "the inability to separate ownership and control in many SMEs suggests the business owners are sole responsible for the development and growth of their enterprises." Some researchers in describing entrepreneurs have considered the traits and characteristics that make an individual act entrepreneurial. Some traits that have been associated with successful entrepreneurs in extant literature include a high need for achievement, propensity for risk-taking and an internal locus of control. (Miner, 1997; McClelland, 1987). "In today's global economy, SMEs that are active players make special efforts to search for diversified growth by pursuing innovation-based production and an open-minded management capable of engaging the appropriate specialised resources, for example, ICTs". (Lal, 2007). Also, Lewis (1977) opines that "what Nigerian entrepreneurs lack the most is managerial competence." The entrepreneur is at the heart of many SMEs in Nigeria and as such determines its strategy through his/her orientation. Lumpkin and Dess (1996) consider entrepreneurial orientation as "the methods, practices and decision making styles managers' use". It is also considered to be a behavioral phenomenon with SMEs being classified as conservative or highly entrepreneurial (Swierczek and Ha, 2003). Entrepreneurial orientation is multidimensional in nature. Miller (1983) considered these dimensions as proactivity, innovation and the propensity to take risk. However, Lumpkin and Dess (1996) included the dimensions of autonomy and competitive aggressiveness to the entrepreneurial orientation construct. While Ogunsiji (2002a) identified ability to identify business opportunities and act on them as the two quintessential characteristics of entrepreneurship. He posited that some archetypal traits- opportunistic, innovative, proactive rather than reactive, high profile image making among others are traits 
that propel entrepreneurial orientation capable to increasing productivity This paper accepts the five dimensions of entrepreneurial orientation to consist of innovation, proactiveness, competitive aggressiveness, risk taking and autonomy.

Innovation, according to Covin and Miles (1999) refers to the tendency of the firm to support new ideas, experiment and create processes earlier than competitors. Innovation will enable the firm to improve on current lines of products, bring into the market new products and use better production techniques or equipment that will enhance productivity. Innovativeness, an attribute of the entrepreneur, refers to the willingness to try new methods which differs from the existing, enthusiasm to bring on board new methods in the way the business is being operated and the willingness to implement the innovative strategy. We believe the firm's innovativeness which is akin to its "distinctiveness" enables the firm to build and capitalise on its competences, leverage on the utilisation of its resources and thus lead to improved competitiveness (Kuratko and Audretsch, 2009; Hitt et. al., 2009). In the present day dynamic environment, the strategic management with its full set of commitments, decisions and actions tends to present sustainable competitive advantage capable of yielding above average returns taming the turbulence in the environment and promoting entrepreneurial re-orientation or what Ferreira and Azevedo (2008) described as strategic entrepreneurship. Literature according to Wong, Ho, and Autio (2005), "suggests that entrepreneurship contributes to economic performance by introducing innovations, creating change, creating competition and enhancing rivalry."

Ventakaraman (1989) considers proactiveness to imply seeking new opportunities that may or may not be related to the existing line of operations. In other words, firms are proactive when they shape their environments i.e. through the introduction of new products and services ahead of competitors, eliminating declining brands, entering new emerging markets ahead of competitors and identifying new opportunities. As uncertain and dynamic as the environment is Kuratko, Montagno, and Hornsby (1990) contended that the pursuit of entrepreneurship as a corporate strategy creates a potentially complex set of challenges. This strategic entrepreneurship involves radically changing internal organisational behaviour patterns. And these patterns instead of creating certainty and stability may otherwise result in ambiguity that keeps threatening managers into pursuing disruptive innovations that deviates from the firms current recipes ( Ireland, Hitt and Sirmon, 2003; Covin, Green and Slevin, 2006). However, if the patterns are handled holistically and proactively with a clear entrepreneurial mindset, an entrepreneurial culture and entrepreneurial leadership, the sustainable competitive advantage of strategic entrepreneurship will engender organisational effectiveness. Proactiveness is the capacity to take the initiative not only in defence but also in the offence. The proactiveness of the enterprise requires the synergistic management of the firm's resources. A firm's resources are vital at enhancing competitiveness and increased productivity. Further, the authors believe the synergistic management of these resources, their allocation and utilisation in the most effective and efficient manners are highly significant to improved productivity. Efficiency, which Ogunsiji and Anene (1994) consider to be "optimal use of resources" is linked with the synergistic management of resources which include capital, labour and technology. These inputs are at the core of productivity measurements in enterprises. Wiklund and Shepherd (2003) reported that knowledge-based resources are enhanced through entrepreneurial orientation. Such resources include marketing and technology capabilities. The synergistic management of the firm's resources will lead to higher quality of inputs, lower costs and improved efficiency of operation.

Risktaking refers to the capacity of the entrepreneur to perceive risk at its inception and to find avenues to mitigate, transfer or share the risk. These risks involve taking the venture into unfamiliar business terrain as well as that of the commitment of resources. Entrepreneurs generally take more risks than non entrepreneurs.

Competitive aggressive refers to a firm's capacity to outweigh and be ahead of rivals at grasping every opportunity. Lumpkin and Dess (1997) consider this as "a firm's strong offensive posture." The management of success is an important aspect of the competition. Geroski (1994) in an econometric study concluded that "competition plays a significant role in stimulating productivity, with both new firms, and new ideas provoking movements to, and outwards movements of, the production frontier which, the data suggest, would not have occurred in their absence". In the light of the above, we concur that "success management" is a competitive phenomenon that has productivity significance on the enterprises. The entrepreneurial management of success is therefore an imperative for improved productivity.

In Nigeria, there is need for a non stop growth, harmonious and balanced blend of resources with the other engines of growth. Each of these engine of growth like people, market, capital, technology and organisation can only flower and blossom fully where the efficacy of entrepreneurial orientation is appreciated and implemented. The focus in Nigeria presently is on the market subsection of the external environment, people within the internal environment, misapplied chunk of capital and mere desire for technological breakthrough to the utter 
neglect of successive and simultaneous delicate blend which is the outright implication of entrepreneurial orientation.

Autonomy which has to do with freedom to articulate and work on one's initiative or convictions as a valid entrepreneurial trait is so much censored in Nigeria to have sustainable comparative advantage on the performance of SMEs. This is in no small measure antithetical to strategic entrepreneurship. Lumpkin and Dess (1996) consider autonomy as the freedom to exercise creativity as individuals or teams at an idea and take it through completion.

\section{Conclusion and Recommendations}

The benefits of Small and Medium Enterprises to an economy, particularly a developing economy like Nigeria is illusory. For such a developing economy, where the twin issues of poverty and unemployment are paramount, and with the attendant ill-conceived plans of resource allocation, it is imperative that the utilization of resources available to SMEs are optimally leveraged. We furthermore consider entrepreneurial orientation as an innovation that should not only be holistic but proactive to facilitate resource combination capable of producing synergy with a clear entrepreneurial mindset operating in an entrepreneurial culture and affording an entrepreneurial leadership. Such an innovative entrepreneur must have the capacity to analyse the variables like skills, motives, attributes, competence, socio-political, technological and economic influences in the internal and external environments to discover the distinctive maneuverability in the market, distinctive competences and unique capability that can generate the desired competitive advantage. The entrepreneurial orientation of the SMEs, evidenced in the owner/manager's orientation is therefore a pre-requisite for improved productivity. This will not only accentuate economic growth and development through existing SMEs but also through nascent entrepreneurs. For the government and other stakeholders, the provision of the enabling environment and other facilities is not only necessary but must also be entrepreneurially utilised for increased productivity.

\section{References}

Adebusuyi, B. S. (1997). Performance Evaluation of Small-Medium Enterprises (SMEs) in Nigeria. CBN Bullion, 21(4): $46-52$.

Adegbite, O. (2001). Business Incubators and Small Enterprise Development: The Nigerian Experience. Small Business Economics, 17: 157-166.

Adegbite, S.E., Ilori, M. O., Irefin, I.A., Abereijo, I. O. \& Aderemi, H. O. S. (2007). Evaluation of the Impact of Entrepreneurial Characteristics on the Performance of Small Scale Manufacturing Industries in Nigeria. Journal of Asia Entrepreneurship and Sustainability, 3(1): 1 - 22.

Akande, O.O. \& Ojokuku, R. M. (2008). The Impact of Entrepreneurial Skills on Small Business Performance in Lagos-South-Western Nigeria. Paper presented at International Council for Small Business, 53 ${ }^{\text {rd }}$ World Conference, Halifax, Nova Scotia, Canada.

Aluko, S.A., Oguntoye, A. O. \& Afonja, A. A. (1975). Small Scale Industries in Western Nigeria. (ed.) Industrial Research Unit, University of Ife, Ile-Ife, 6 - 8.

Baumol, W.J. (1993). Entrepreneurship, Management and the Structure of Payoffs. Cambridge, MA: MIT Press.

Beyene, A. (2002). Enhancing the Competitiveness and Productivity of Small and Medium Scale Enterprises (SMEs) in Africa: An Analysis of Differencial Roles of National Governments Through Improved Support Services. Africa Development, 27(3) : 130-156.

Covin, J.G., Green, K. M. \& Slevin, D. P. (2006). Strategic Process Effects on the Entrepreneurial Orientation-Sales Growth Rate Relationship. Entrepreneurship Theory and Practice, 30(1), 57-81.

Covin, J.G. \& Miles, M. P. (1999). Corporate Entrepreneurship and the Pursuit of Competitive Advantage. Entrepreneurship Theory and Practice, 23(3): 47- 63.

Covin, J.G. \& Slevin, D. P. (1989). Strategic Management of Small Firms in Hostile and Benign Environments. Strategic Management Journal, 10: 75-87.

Ferreira, J. \& Azevedo, S. G. (2008). Entrepreneurial Orientation (EO) and Growth of Firms: Key Lessons for Managers and business Professionals. Problems and Perspectives in management, 6(1): 81-87.

Geroski, P. (1994). Market Structure, Corporate Performance and Innovative Activity. Oxford, UK: Oxford University Press.

Hallberg, K. (2000). A market Oriented Strategy for Small and Medium-Scale Enterprises. IFC Discussion Paper 40. http//: www.ifc.org (June 17, 2009). 
Hitt, M. A., Ireland, R.D. \& Hoskisson, R.E. (2009). Strategic Management: Competitiveness and Globalization, ( $8^{\text {th }}$ ed.). Mason, $\mathrm{OH}$ : Cengage Learning.

Inyang, B. J. \& Enuoh, R. O. (2009). Entrepreneurial Competencies: The Missing Links to Successful Entrepreneurship in Nigeria. International Business Research, 2(2): 62-71.

Ireland, R. D., Hitt, M. A. \& Sirmon, D. G. (2003). A Model of Strategic Entrepreneurship: the Construct and its Dimensions. Journal of Management, 29: 1-26.

Kharbanda, V.P. (2001). Facilitating Innovation in Indian Small and Medium Enterprises-the Role of Clusters. Current Science, 80(3): 343 - 348.

Kuratko, D.F. and Audretsch, D. B. (2009). Strategic Entrepreneurship: Exploring Different Perspectives of an Emerging Concept. Entrepreneurship Theory and Practice, 33(1): 1-17.

Kuratko, D. F., Montagno, R. V. \& Hornsby, J. S. (1990). Developing Entrepreneurial Assessment Instrument for Effective Entrepreneurial Environment. Strategic Management Journal, (2): 49-58.

Ladanu, W.K. (2009). Sustainable Development and Financing of Small and Medium Enterprises in Nigeria: The Journey So Far. Journal of Business Administration and Management . 4(1): 43-49.

Lal, K. (2007). Globalisation and the Adoption of ICTs in Nigerian SMEs. Science, Technology \& Society. 12(2): 217-244.

Lebell, D., Schultz, K. \& Weston, J. F. (1974). Smalll-Scale Industries and Developing Countries. California Management Review, 17 (1): 32-39.

Lewis, W.A. (1977). Reflections on the Structure of Nigerian Manufacturing Industry. In O. Teriba, \& M.O. Kayode (Eds.), Industrial Development in Nigeria: Patterns, Problems and Prospect. Ibadan, Oyo State: Ibadan University Press.

Lumpkin, G. T. \& Dess, G. G. (1996). Clarifying the entrepreneurial orientation construct and linking it to performance. Academy of Management Review, 21(1): 135-172.

Lumpkin, G. \& Dess, G. (1997). Proactiveness Versus Competitive Aggressiveness: Teasing Apart Key Dimensions of an Entrepreneurial Orientation. In P. D. Reynolds, W. D. Bygrave, N. M. Carter, P. Davidsson, W. B. Gartner, C. M. Mason \& P. McDougall (Eds.), Frontiers of Entrepreneurship Research. Babson Park, MA: Babson College.

McClland, D.C. (1987). Characteristics of Successful Entrepreneurs. Journal of Creative Behaviour, 21(3): 219-233.

Miller, D. (1983). The Correlates of Entrepreneurship in Three Types of Firms. Management Science, 29(7): 770-791.

Miner, J.B. (1997). A Psychological Typology and its Relationship to Entrepreneurial Success. Entrepreneurship and Regional Development. 9(4): 319-334.

Nigerian Investment Promotion Commission (2004), Overview of Small and Medium Scale Enterprises in Nigeria . An Information Booklet, Abuja. 1-33.

OECD (1998). Annual Competitiveness Report SME Performance. OECD, Paris.

OECD (2004). Small and Medium-Sized Enterprises in Turkey: Issues and Policies. OECD, Paris.

Ogun, O., and J. C. Anyanwu (1999). Financing Small and Medium Enterprises in Nigeria : Lessons From International Experience. The Nigerian Financial Review, 8(1) : 12-21.

Ogunsiji, A.S. (2002a). Agricultural Credit Strategies and Productivity Performance of Small Scale Agro-based Industries. Research Communications in Management, 1(2): 42-50.

. (2002b). The Practice and Impact of Strategic Management in Small Scale Industry

Performance in Oyo State, Nigeria. Ph.D. Dissertation, Departmentnt of Management Science, Ladoke Akintola University of Technology, Ogbomoso Nigeria.

. (2004). Strategic Management in the Hand of an Excellent Manager Will Improve Productivity;

But What Won't : A Discourse. International Journal of Socio-Economic Development and Strategic Studies, (1): 86-94.

(2005). Managing Strategic Surprises/Failures in Small Scale Transport Enterprises. Adamawa State University Business Journal. (1) : 8-13. 
Ogunsiji, A.S. \& Anene, E. C. (1994). Productivity and Efficiency in the Private Sector: A Managerial Perspective, In O. L. Oludimu, \& J. O. Fasanya (Eds.), Corporate Strategy Policy and Decision Making. Ogbomoso, Oyo State: Asogun Books.

Oludimu, O.L. \& Ogunsiji, A. S. (1994). Productivity and Economic Performance of Rural Industries: A Case Study. In O. L. Oludimu, \& J. O. Fasanya (Eds.), Corporate Strategy Policy and Decision Making. Ogbomoso, Oyo State: Asogun Books.

Olutunla, G.T. \& Obamuyi, T. M. (2008). An Empirical Analysis of Factors Associated with The Profitability of Small and Medium-enterprises in Nigeria. African Journal of Business Management. 2(10): 195-200.

Roberts, M.J. \& Tybout, J. R. (1997). Producer Turnover and Productivity Growth in Developing Countries. The World Bank Research Observer, 12(1): 1-18.

Swierczek, F.W. \& Ha, T. T. (2003). Entrepreneurial Orientation, Uncertainty Avoidance and Firm Performance. Entrepreneurship and Innovation, 4(1): 46 - 58.

Teece, D.J., Pisano, G. \& Schuen, A. (1997). Dynamic Capabilities and Strategic Management. Strategic Management Journal, 18(7): 509-533.

Ventakaraman, N. (1989). Strategic Orientation of Business Enterprises: The Construct, Dimensionality and Measurement. Management Science, 35: 942-962.

Wiklund, J. \& Shepherd, D. (2003). Knowledge-Based Resources, Entrepreneurial Orientation and the Performance of Small and Medium-sized Businesses. Strategic Management Journal, 24(13): 1307-1314.

Wong, P.K., Ho, Y. P. \& Autio, E. (2005). Entrepreneurship, Innovation and Economic Growth: Evidence from GEM Data. Small Business Economics, 24: 335-350.

World Bank, (2002). An Assessment of the Private Sector in Nigeria, Regional Program On Enterprise Development, Africa Private Sector Department. Small and Medium Enterprises Department, Washington, D.C., World Bank

Yu, T.F.L. (2001). Towards a Capabilities Perspective of the Small Firm. International Journal of Management Reviews, 3(3): 185-197.

Zahra, S. (1993). A Conceptual Model of Entrepreneurship as Firm Behavior: A Critique and Extension. Entrepreneurship Theory and Practice, 14(4): 5-22.

Table 1. Micro Small and Medium Enterprises Definitions

\begin{tabular}{|l|l|l|l|l|l|l|l|l|l|l|}
\hline & \multicolumn{3}{|l|}{$\begin{array}{l}\text { Assets Excluding Real } \\
\text { Estate (million Naira) }\end{array}$} & \multicolumn{2}{l|}{$\begin{array}{l}\text { Annual Turnover } \\
\text { (In million Naira) }\end{array}$} & \multicolumn{3}{l|}{ Number of Employees } \\
& Med & Small & Micro & Med & Small & Micro & Med & Small & Micro \\
\hline Central Bank of Nigeria & $<150$ & $<1$ & & $<150$ & $<1$ & & $<100$ & $<50$ & \\
\hline NERFUND & & $<10$ & & & & & & & \\
\hline NASSI & & $<40$ & $<1$ & & $<40$ & & & $3-35$ & \\
\hline Min. of Industry* & $<200$ & $<50$ & & & & & $<300$ & $<100$ & $<10$ \\
\hline NASME & $<150$ & $<50$ & $<1$ & $<500$ & $<100$ & $<10$ & $<100$ & $<50$ & $<10$ \\
\hline Arthur Andersen & & & & $<500$ & $<50$ & & & & \\
\hline
\end{tabular}

${ }^{a}$ National Council of Industry under the Ministry of Industry revises SME definition once a year.

Source: World Bank 2002.

Table 1 gives some definitions of micro, small and medium enterprises by some Nigerian government and private agencies. 
Table 2. Index of Manufacturing Production in Nigeria 1986-2006 (1985=100)

\begin{tabular}{|c|c|c|}
\hline Year & Index & Percentage Change \\
\hline 1986 & 96.1 & ---- \\
\hline 1987 & 128.4 & 33.6 \\
\hline 1988 & 135.2 & 5.3 \\
\hline 1989 & 154.3 & 14.1 \\
\hline 1990 & 162.9 & 5.6 \\
\hline 1991 & 178.1 & 9.3 \\
\hline 1992 & 169.5 & -4.8 \\
\hline 1993 & 145.5 & -14.2 \\
\hline 1994 & 144.2 & -0.9 \\
\hline 1995 & 136.2 & -5.5 \\
\hline 1996 & 138.7 & 1.8 \\
\hline 1997 & 138.5 & -0.1 \\
\hline 1998 & 133.1 & -3.9 \\
\hline 1999 & 137.7 & 3.5 \\
\hline 2000 & 138.2 & 0.4 \\
\hline 2001 & 142.2 & 2.9 \\
\hline 2002 & 146.3 & 2.9 \\
\hline 2003 & 148.0 & 1.2 \\
\hline 2004 & 145.7 & -1.6 \\
\hline 2005 & 145.8 & 0.1 \\
\hline 2006 & 145.7 & -0.1 \\
\hline
\end{tabular}

Source: Central Bank of Nigeria Statistical Bulletin (2007).

Table 2 shows the index of manufacturing in Nigeria between 1986 and 2006, a twenty year period.

The table highlights the dwindling of productivity fortunes for enterprises in the manufacturing sector in the Nigerian economy.

Table 3. Industrial Capacity Utilisation (Percent)

\begin{tabular}{|c|l|c|c|c|c|c|c|}
\hline & \multicolumn{1}{|c|}{ Sectors } & & & & & \\
S/N & & 2002 & 2003 & 2004 & 2005 & 2006 & 2007 \\
\hline 1 & Food Beverages \& Tobacco & 58.85 & 53.7 & 41.32 & 43.73 & 50.25 & 48.05 \\
\hline 2 & Textile Apparel \& Footwear & 44.9 & 50.75 & 36.2 & 47.5 & 36.6 & 51.25 \\
\hline 3 & wood \& wood products & 55.75 & 53.45 & 45.25 & 35.5 & 42.4 & 65 \\
\hline 4 & Pulp, Paper \& Publishing & 65.75 & 49.65 & 69 & 35.37 & 46.1 & 52.4 \\
\hline 5 & Chemical \& Pharmaceutical & 51.8 & 56 & 32.82 & 41.42 & 41.1 & 48.6 \\
\hline 6 & Non-metallic \& Mineral Products & 50.05 & 57.5 & 60.6 & 77.35 & 64.55 & 66.5 \\
\hline 7 & Domestic/Industrial Plastic \& Rubber & 53.6 & 56.9 & 43.52 & 52.22 & 50.42 & 48.25 \\
\hline 8 & Electrical \& Electronics & 41.1 & 32.1 & 41.25 & 50 & 38.95 & 56.05 \\
\hline 9 & Basic Metal, Iron \& Steel & 49.65 & 48.8 & 46.53 & 48.28 & 50.5 & 41.6 \\
\hline 10 & Motor Vehicle \& Miscelleneous Assembly & 41.3 & 30.15 & 33.72 & 25.93 & 33.8 & 27.5 \\
\hline
\end{tabular}

Source: Manufacturers' Association of Nigeria, Biannual Report, Various Issues.

Table 3 also adds credence to the fact that low levels of performance exist in the manufacturing sector of the Nigerian economy. The table indicates, on the whole, an average or below average performance in the industrial capacity utilisation in the various sectors. 